\title{
Editorial
}

\section{Mais espaço, mais pesquisa}

Nosso leitor certamente percebeu que, desde sua penúltima edição, a revista Discursos Fotográficos está apresentando 10 artigos, ao invés dos 8 artigos que vinha publicando ao longo dos últimos anos. Provavelmente a quantidade de artigos por edição vai crescer nos próximos números, pois estamos recebendo várias submissões. Por sua vez, a seção Dissertações, que apresentava os resumos das dissertações defendidas no Programa de Pós-Graduação em Comunicação da Universidade Estadual de Londrina, será cancelada, acompanhando a mesma decisão de outros periódicos científicos da área. Entretanto, o leitor pode encontrar esse material no banco de dissertações, disponível no acervo digital do site do programa (http://www.uel.br/pos/mestradocomunicacao/). Essas são algumas das muitas mudanças programadas para fortalecer a divulgação de artigos e pesquisas promovida por esta revista. Esperamos que essas mudanças, bem como outras vindouras, assegurem o patamar de referência alcançado pela Discursos Fotográficos.

"Fotografar prejudica a memória?" é a pergunta que Nina Cruz e Manuela Salazar fazem no artigo de abertura desta edição. As autoras discutem as múltiplas relações entre o ato de fotografar e a memória, levantando alguns questionamentos contemporâneos, próprios da nossa era digital: $\mathrm{O}$ ato de fotografar prejudica a construção de memórias? Ele nos ajuda a lembrar, ou o acúmulo de fotografias atrapalha a formação de lembranças?

Também dialogando com a fotografia na era digital, o artigo "Taxonomia fotográfica: uma proposta metodológica para a pesquisa dos selfies em redes sociais", de Hertez de Camargo e Josemara Stefaniczen, elabora uma interpretação desse gênero fotográfico e apresenta os caminhos metodológicos para a análise do autorretrato no Instagram. Os autores entendem que é possível 
desenvolver uma taxonomia do selfie aplicável a outros gêneros fotográficos presentes na cultura midiática.

Patricia Karina Natalia Schwarz, em "Fotografías en el espacio virtual. Aspectos éticos y epistémico-metodológicos de su análisis en Ciencias Sociales", também discute questões metodológicas a respeito de fotografias online, concentrandose em seu uso no campo das ciências sociais. Além do debate metodológico, o artigo expõe os cuidados éticos que esse tipo de fotografia exige quando utilizada em pesquisas científicas.

O autorretrato, em sua versão tradicional, também é abordado por Agustina Triquell em "Mi mirada en el espejo. El autorretrato como afirmación del autor. Una etnografía del campo fotográfico argentino". Ao adotar a pesquisa etnográfica, aplicada na produção argentina dos últimos trinta anos, o artigo questiona as relações entre fotografia autoral e imagem do eu, compreendendoas como modos de enunciação da subjetividade.

Em "A recriação poética da palavra na fotografia do filme O veneno da madrugada, de Ruy Guerra", Ana Carolina Tavares e Josette Monzani apresentam alguns aspectos referentes à fotografia de $\mathrm{O}$ veneno da madrugada (2006), dirigido por Ruy Guerra. Entende-se que a luminosidade do quadro fílmico ressalta os sentidos de dualidade e ambiguidade presentes em La mala hora (1962), romance de Gabriel García Márquez que inspirou o filme.

Em consonância com o dossiê apresentado na última edição da Discursos Fotográficos, o artigo "O ícone da derrota: a construção do $7 \mathrm{x} 1$ pela plasticidade visual" investiga esse acontecimento esportivo como um arranjo de significados visuais que produz sentidos acerca do resultado. Analisando capas de jornal, Magnos Casagrande e Fabiano Maggioni entendem que, ao contrário do que frequentemente se pensa, o signo icônico possui flexibilidade para representar o real, através de elementos visuais como a cor, o ponto, a textura e a dimensão.

$\mathrm{O}$ artigo "A retórica da imagem na grande reportagem transmídia", de Mauro Ventura e Liliane Ito, mostra como o 
fotojornalismo também pode se aproximar da publicidade. Considerando a metodologia proposta por Umberto Eco em A Estrutura Ausente e analisando fotografias produzidas para uma reportagem digital, os autores descobrem articulações semelhantes às observadas em peças publicitárias, apesar de certas diferenciações.

A partir de uma perspectiva interdisciplinar em cotejo com variadas posições teóricas, Diego Canhada e Samir de Oliveira discutem tópicos de filosofia da linguagem em "Pantaleão e as visitadoras: análise sócio-organizacional do filme peruano baseado no livro de Vargas Llosa". Para promover essa discussão, os autores destacam passagens do filme peruano e realizam análises sobre as mesmas.

O fotolivro, gênero pouco pesquisado até então, é o tema do artigo "Semiose e intermidialidade nos fotolivros Silent Book e Sí por Cuba", de Ana Paula Vitorio e João Queiroz. Tomando essas obras como exemplos paradigmáticos do gênero e baseandose nos estudos de intermidialidade e na semiótica peirciana, os autores pontuam alguns processos característicos das relações intermidiáticas presentes nas obras, como o uso dos aspectos materiais e dos espaços ocupados pelas fotografias.

Transversalmente, o artigo "Uma análise sobre a formação discursiva na comunicação organizacional do Sesi: o discurso da educação, saúde e trabalho na revista Sesinho", de Marlene Royer, Rozinaldo Miani e Daniel Figueiredo, questiona como a linguagem dos quadrinhos, apropriada pela revista em questão, desenvolve a comunicação organizacional da instituição analisada. Por meio da Análise do Discurso, o artigo identifica os processos de construção dos temas educação, saúde e trabalho presentes na linguagem iconográfica dos quadrinhos.

Encerrando esta edição com a seção "Resenhas", para complementar os diversos artigos desta edição que abordam a fotografia online, Sergio Cáceres faz uma apresentação crítica do livro "Métodos de pesquisa para internet", de Suely Fragoso, Adriana Amaral e Raquel Recuero. Publicado originalmente 
em 2011 pela Editora Sulina, esta obra ainda é uma das poucas referências em língua portuguesa para os interessados em pesquisar o não tão novo, mas ainda assim desafiante, universo da internet.

Rodolfo Rorato Londero 